\title{
ARCTIC SOIL CLASSIFICATION AND PATTERNED GROUND*
}

\author{
J. V. Drew and J. C. F. Tedrowì
}

\begin{abstract}
$\mathbf{P}$
EDOLOGIC studies in the region of continuous permafrost of northern Alaska have revealed a number of genetic soils. These soils have been characterized in terms of their morphology, landscape relationships, geographic range (Tedrow et al. 1958), and seasonal depth of thaw (Drew et al. 1958). In carrying out these field studies it became apparent, however, that certain kinds of arctic microrelief or patterned ground are often associated with specific genetic soils. Furthermore, patterned ground is often responsible for major variations in soil conditions within a genetic soil body. The purpose of this paper is to point out certain relationships among arctic soils and patterned ground and to suggest a scheme for the classification of soils associated with arctic microrelief.
\end{abstract}

\section{Major genetic soils}

With the exception of a few highly generalized soil maps little attempt has been made to classify and map soils in the arctic regions of the world. Studies in northern Alaska indicate, however, that the soil-forming factors of climate, parent material, relief, organisms, and time have produced certain distinctive soil features that may be used to classify soils into several major genetic groupings, which include Lithosols, Regosols, Arctic Brown, Tundra, and Bog.

Lithosols and Regosols form either on very young land surfaces or from parent materials that are excessively drained or highly resistant to the soil-forming processes. These soils are similar in many respects to their

*Contribution from the Nebraska Agricultural Experiment Station, Dept. of Agronomy, and New Jersey Agricultural Experiment Station, Rutgers University, the State University of New Jersey, Department of Soils. Published with the approval of the Director as paper No. 999, Journal Series, Nebraska Agricultural Experiment Station.

These studies were aided by a contract between the O.N.R., Dept. of the Navy, and the Arctic Institute of North America. Reproduction in whole or in part permitted for any purpose by the United States Government.

$\dagger$ Dept. of Agronomy, University of Nebraska, and Dept. of Soils, Rutgers University, respectively. 
counterparts in temperate regions, but often show profile features grading toward Arctic Brown soil. Arctic Brown soil develops on stable positions such as narrow ridge tops, escarpment edges, or old terrace edges, where annual depth of thaw (the active layer) approximates 4 or more feet, allowing the soil profile to develop under relatively free, but not excessive drainage.

Tundra and Bog soils mantle the rolling and level areas of northern Alaska, thaw usually to depths of 18 inches or less, usually approach moisture saturation, and show effects of gleization. On nearly level areas and long slopes up to 8 to 10 per cent, the underlying mineral parts of Tundra soils are dominantly grey to greyish brown and slightly mottled. These soils have been designated Meadow Tundra. Upland Tundra, a more oxidized and mottled segment of Tundra soil, develops on shorter or steeper slopes. It should be pointed out that the genetic interpretation of gleization in Upland Tundra and Meadow Tundra soils is at times rather difficult. In many instances Tundra soils have developed on topography that has been shaped by cryoplanation, on materials disturbed by frost action, or from materials laid down on flood plains or in thaw-lake basins. These processes of frost action and sedimentation tend to bury or mix surface or organic-stained material with mineral material occurring below the surface. Chemical and biological processes operating in this cold soil environment are slow to obliterate the heterogeneous colours of these mixed materials, and depositional patterns or local mottles of organic stain may be mistaken for the effects of gleization. Bog soils occupy level or depressed areas and exhibit morphologies similar to the Bog soils of temperate regions, except that permafrost occurs near the surface.

\section{Relation of soils to patterned ground}

In certain areas of the Alaskan Arctic Slope relatively uniform bodies of soil may be distinguished according to the differentiae presented for the major genetic soils. In other areas, however, these soils are associated with patterned ground and this creates a complex mosaic of soil conditions across the landscape. Often specific forms of patterned ground are associated with each major genetic soil (Table 1). It would be unusual, for example, to encounter a Bog soil in association with stone garlands; these forms of patterned ground would more likely be found with Regosol or Arctic Brown soil. Similarly, Arctic Brown soil would not occur with strangmoor, i.e., a bog covered with narrow, more or less parallel ridges of peat that are separated by strips of bog soil or standing water; instead, Bog or Meadow Tundra soils would be present.

Various authors have used a number of terms to describe arctic patterned ground. For purposes of this study terminology from the unified classification scheme of Washburn (1956) has been adopted. Table 1 indicates that stone polygons, stone nets, steps and stone garlands, and stone stripes are often associated with well-drained soils. Peat rings, frost boils, 
Table 1. Generalized relationships of patterned ground to the major genetic soils of northern Alaska; classification of patterned ground adapted from Washburn (1956). Polygon types A, B, C, D, E, E, and F are illustrated in Fig. 5.

\begin{tabular}{|c|c|c|c|c|c|}
\hline \multirow{2}{*}{$\begin{array}{l}\text { Patterned } \\
\text { ground }\end{array}$} & \multicolumn{2}{|c|}{$\begin{array}{l}\text { Soils formed under } \\
\text { well-drained conditions }\end{array}$} & \multicolumn{3}{|c|}{$\begin{array}{l}\text { Soils formed under conditions } \\
\text { of impeded drainage }\end{array}$} \\
\hline & $\begin{array}{c}\text { Lithosols } \\
\text { and Regosols }\end{array}$ & $\begin{array}{l}\text { Arctic } \\
\text { Brown }\end{array}$ & $\begin{array}{l}\text { Upland } \\
\text { Tundra }\end{array}$ & $\begin{array}{l}\text { Meadow } \\
\text { Tundra }\end{array}$ & Bog \\
\hline $\begin{array}{l}\text { Sorted } \\
\text { circles }\end{array}$ & $\begin{array}{l}\text { Stone } \\
\text { rings }\end{array}$ & $\begin{array}{l}\text { Stone } \\
\text { rings }\end{array}$ & Stone rings & & \\
\hline $\begin{array}{l}\text { Non-sorted } \\
\text { circles }\end{array}$ & & & $\begin{array}{l}\text { Peat rings } \\
\text { Tussock rings } \\
\text { Frost boils }\end{array}$ & $\begin{array}{l}\text { Peat rings } \\
\text { Tussock rings } \\
\text { Frost boils }\end{array}$ & \\
\hline $\begin{array}{c}\text { Sorted } \\
\text { polygons }\end{array}$ & $\begin{array}{c}\text { Stone } \\
\text { polygons }\end{array}$ & $\begin{array}{c}\text { Stone } \\
\text { polygons }\end{array}$ & & & \\
\hline $\begin{array}{l}\text { Non-sorted } \\
\text { polygons }\end{array}$ & & $\begin{array}{c}\text { Ice-wedge } \\
\text { polygons } \\
\text { (Types A } \\
\text { and B) }\end{array}$ & $\begin{array}{l}\text { Ice-wedge } \\
\text { polygons } \\
\text { (Types A, } \\
\text { B, and F) }\end{array}$ & $\begin{array}{c}\text { Ice-wedge } \\
\text { polygons } \\
\text { (Types B, C, } \\
\text { D, E, F) } \\
\text { Tussock-birch- } \\
\text { heath polygons }\end{array}$ & $\begin{array}{l}\text { Ice-wedge } \\
\text { polygons } \\
\text { (Types C } \\
\text { and } \mathrm{F} \text { ) } \\
\end{array}$ \\
\hline $\begin{array}{l}\text { Sorted } \\
\text { nets }\end{array}$ & $\begin{array}{l}\text { Stone } \\
\text { nets }\end{array}$ & & & & \\
\hline $\begin{array}{l}\text { Non-sorted } \\
\text { nets }\end{array}$ & $\begin{array}{l}\text { Vegetation } \\
\text { nets }\end{array}$ & & $\begin{array}{l}\text { Mounds } \\
\text { Vegetation } \\
\text { nets }\end{array}$ & $\begin{array}{l}\text { Bog ridges } \\
\text { Mounds }\end{array}$ & $\begin{array}{l}\text { Bog ridges } \\
\text { Ice Mounds }\end{array}$ \\
\hline $\begin{array}{l}\text { Sorted } \\
\text { steps }\end{array}$ & $\begin{array}{l}\text { Steps and } \\
\text { stone } \\
\text { garlands }\end{array}$ & & & & \\
\hline $\begin{array}{l}\text { Sorted } \\
\text { stripes }\end{array}$ & $\begin{array}{l}\text { Stone } \\
\text { stripes }\end{array}$ & & & & \\
\hline $\begin{array}{l}\text { Non-sorted } \\
\text { stripes }\end{array}$ & $\begin{array}{c}\text { Soil } \\
\text { stripes }\end{array}$ & $\begin{array}{c}\text { Soil } \\
\text { stripes }\end{array}$ & $\begin{array}{c}\text { Soil } \\
\text { stripes }\end{array}$ & & \\
\hline
\end{tabular}

tussock rings, ice-wedge polygons, bog ridges, and ice mounds are often associated with poorly drained soils. Whereas certain forms of patterned ground usually occur under specific types of drainage, other forms exist in a broader range of soil conditions. For example, stone rings or vegetation nets may occur with Lithosols, Regosols, and Arctic Brown soils, and also with certain Upland Tundra soils. Ice-wedge polygons are usually associated with Tundra and Bog soils, but certain types may occur with welldrained soils.

\section{The integration of the classification of soil and patterned ground}

Field studies in northern Alaska indicate that it is often difficult to apply concepts of soil morphology and classification developed in temperate regions to the study of arctic soils. In the Arctic the presence of permafrost complicates soil properties, soil horizons may not follow a uniform sequence, 

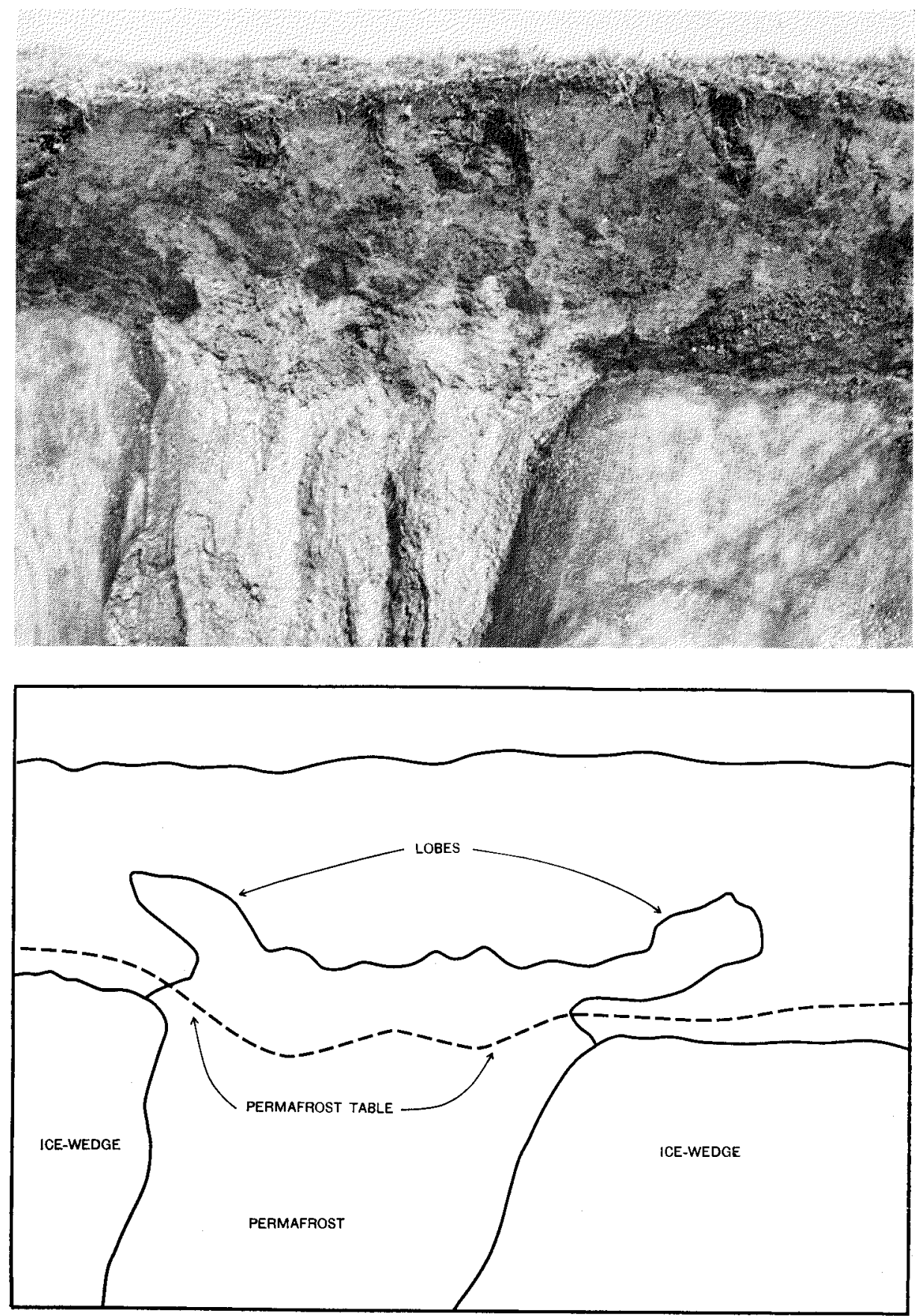

Fig. 1. Cross-section through the corner of an ice-wedge polygon. The diagram identifies areas of ground ice, permafrost, and disturbed soil in the photograph. Note the upward displacement of lobes of soil material adjacent to the upper edges of the ice-wedges. 
and soil conditions often vary more abruptly and repetitively than in temperate regions (Tedrow and Cantlon 1959). On account of the effects of permafrost, frost action, and patterned ground, the authors believe that it is necessary to employ microrelief as well as soil morphology in developing a classification scheme for arctic soils.

Although soil development in the Arctic is slow, certain genetic soil characteristics develop as the result of pedogenic processes. As soil development progresses, differences in content of organic matter, colour, structure, and other properties become apparent among soil horizons. When patterned ground is associated with these soils, however, the additional factors of frost action, and the microrelief of patterned ground itself, influence soil morphology. In extreme cases frost action on steep slopes may move soil material downslope at a rate sufficient to prevent a genetic soil morphology from developing.

In well-drained soils the development of soil stripes or vegetation nets across an area of Regosol, Lithosol, or Arctic Brown soil affects the thickness and continuity of genetically developed organic-mineral or surface organic soil layers. In another case the physical sorting of coarse and fine soil materials by frost action during the formation of sorted circles, polygons, or nets influences the development of a normal genetic morphology. Conversely, the lack of disturbance in a genetic horizon sequence suggests that frost action has not been severe during the period in which genetic soil horizons have developed (Tedrow 1961).

In poorly drained soils, patterned ground influences the distribution of soil moisture and organic and mineral material within a soil body as well as the thickness and continuity of surface organic layers. The microrelief of ice-wedge polygons resulting from the thawing of ground ice, or the physical displacement of soil by the growth of ground ice illustrates certain of these soil conditions. A high-centre ice-wedge polygon developed by the thawing of ice-wedges may have a moderately well-drained upper surface, whereas the trough at its periphery may contain standing water (Fig. 4). In the Arctic soil morphology is slow to reflect changes in moisture conditions of the environment (Douglas and Tedrow 1959), and the soil in the polygon centre may be similar to that in the polygon trough, except for moisture content. These differences in relative wetness are reflected in the composition of associated plant communities (Wiggins 1951). The effect of the growth of ice-wedges on soil morphology is illustrated in Fig. 1. Black (1954) has shown that ice-wedges may grow at rates up to $1.5 \mathrm{~mm}$. per year. Pressures produced in the soil by the expansion of ice-wedges cause soil material to be squeezed and contorted, and may elevate the adjacent soil surface.

Using ice-wedge polygons as an example it is possible to integrate the patterned-ground classification of Washburn (1956) with pedology to develop an overall classification for arctic soils. In accomplishing this, however, the terminology of Washburn for ice-wedge polygons requires certain modifications. Variations in microrelief and soil moisture conditions within 


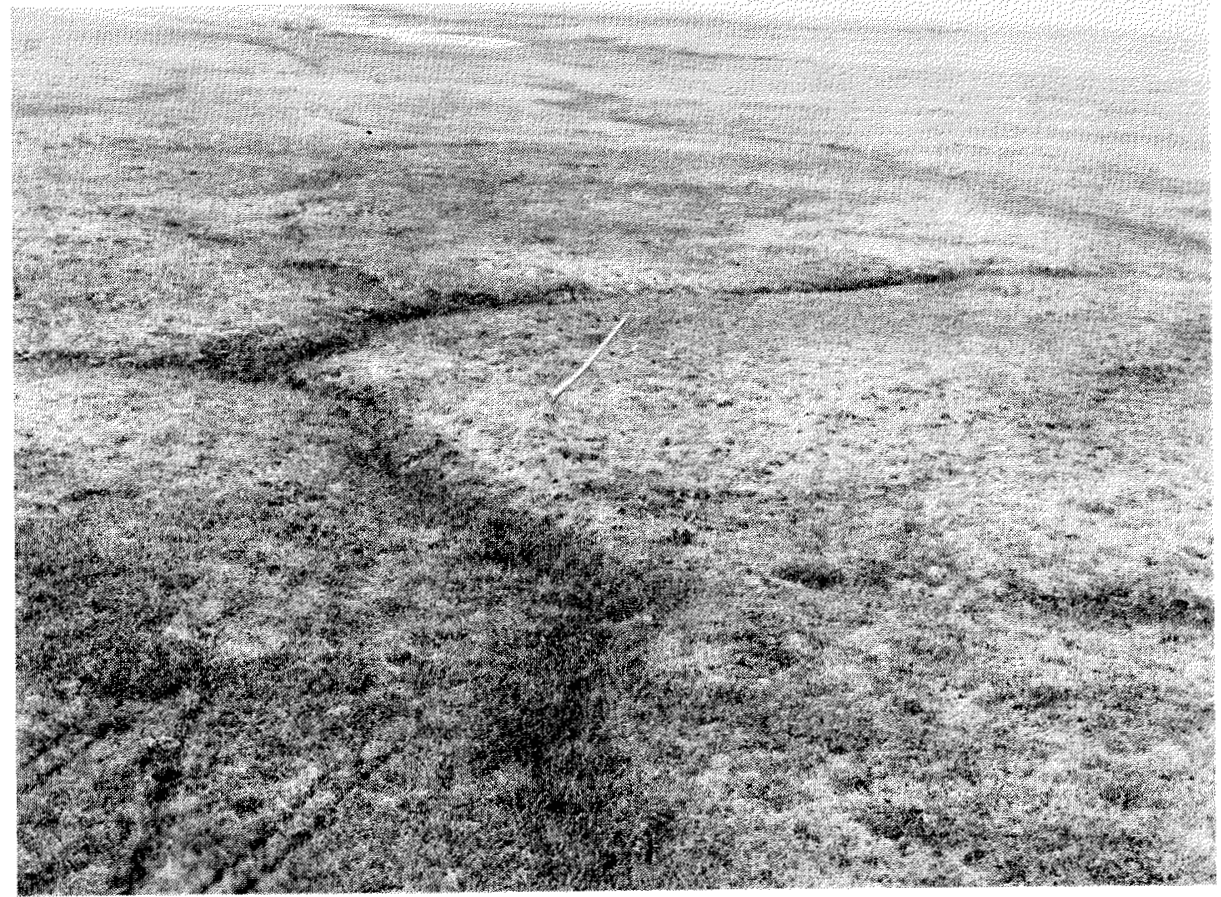

Fig. 2. A-type ice-wedge polygons associated with Upland Tundra soil, Point Barrow, Alaska.

high-centre and low-centre ice-wedge polygons require refinement in the classification of these forms of patterned ground. Fig. 5 illustrates a proposed classification of ice-wedge polygons to fill this need. Polygons of the A-type (Fig. 2) and B-type differ in degree of trough development, whereas C-, D(Fig. 3), and E-type polygons exhibit a consecutive increase in ridge width and height. F-type polygons (Fig. 4) show the most pronounced microrelief.

Ice-wedge polygons representing these types exist across broad areas of northern Alaska. It is possible to classify their associated soils in terms of genetic soil profile characteristics, and the range of soil conditions created by patterned ground. For example, if Meadow Tundra is the dominant genetic soil, and the associated patterned ground can be classed as D- and E-type ice-wedge polygons, then the compound term "Meadow Tundra with D-E Ice-Wedge Polygons" classifies the soil in terms of major profile features as well as the range of microrelief and soil moisture conditions. Since the permafrost table closely follows the surface microrelief in areas of ice-wedge polygons, this classification system also indicates the ease of travelling over each type of soil area. The frozen ridges or centres of B, C, D, E, and F polygons are less readily traversed with tracked vehicles than similar soils lacking these microrelief features.

Other forms of patterned ground, such as tussock-birch-heath polygons, frost boils, peat rings, tussock rings (Hopkins and Sigafoos 1950), mounds, 


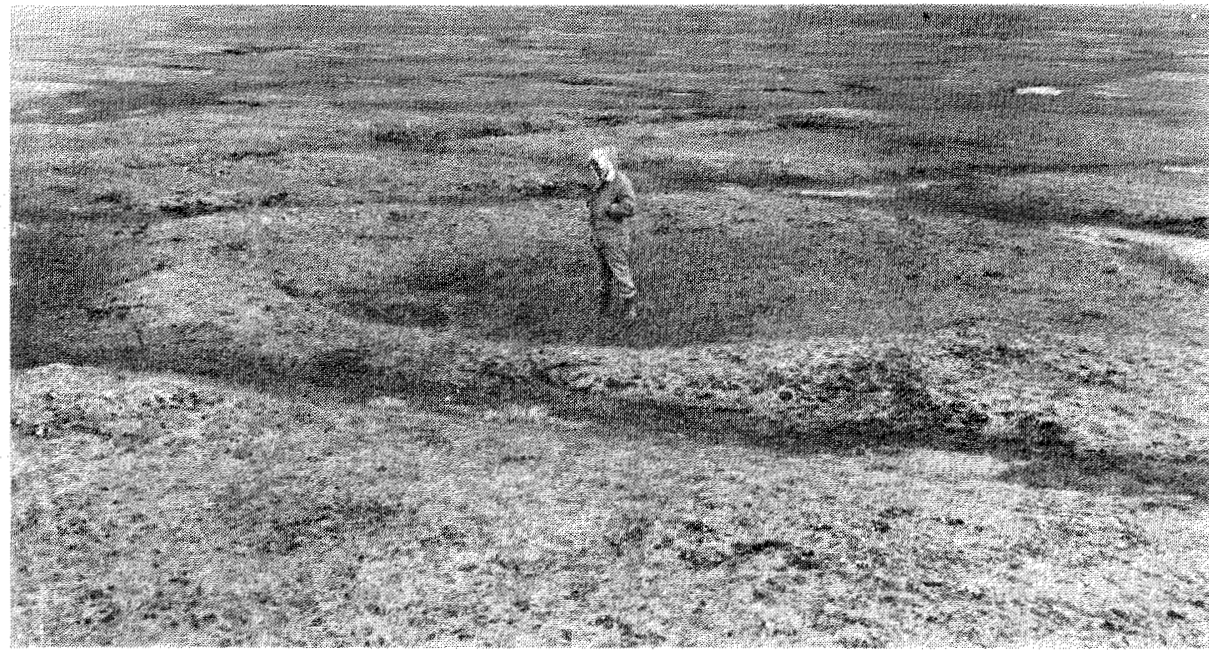

Fig. 3. D-type ice-wedge polygons associated with Meadow Tundra soil, Point Barrow, Alaska.

(Tedrow and Cantlon 1959), and bog ridges also influence soil morphology. These features may occur independently or as secondary forms on the surfaces of primary ice-wedge polygons. When highly complex areas of patterned ground occur it may be necessary to include several forms of patterned ground in the classification of a single soil. In other cases a classification term including one soil and one patterned-ground name may suffice. Results obtained in several test areas in northern Alaska indicate that this procedure provides an approach to the classification of arctic soils associated with patterned ground (Drew 1957).

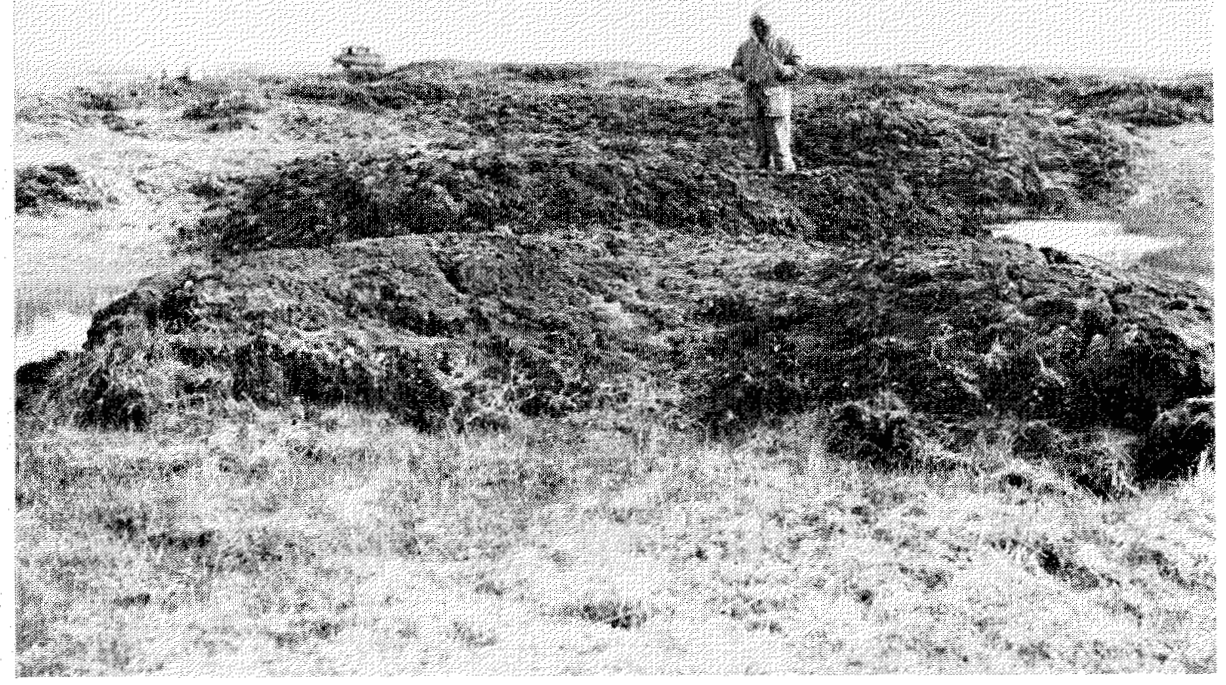

Fig. 4. F-type ice-wedge polygons associated with Bog soil, Point Barrow, Alaska. 


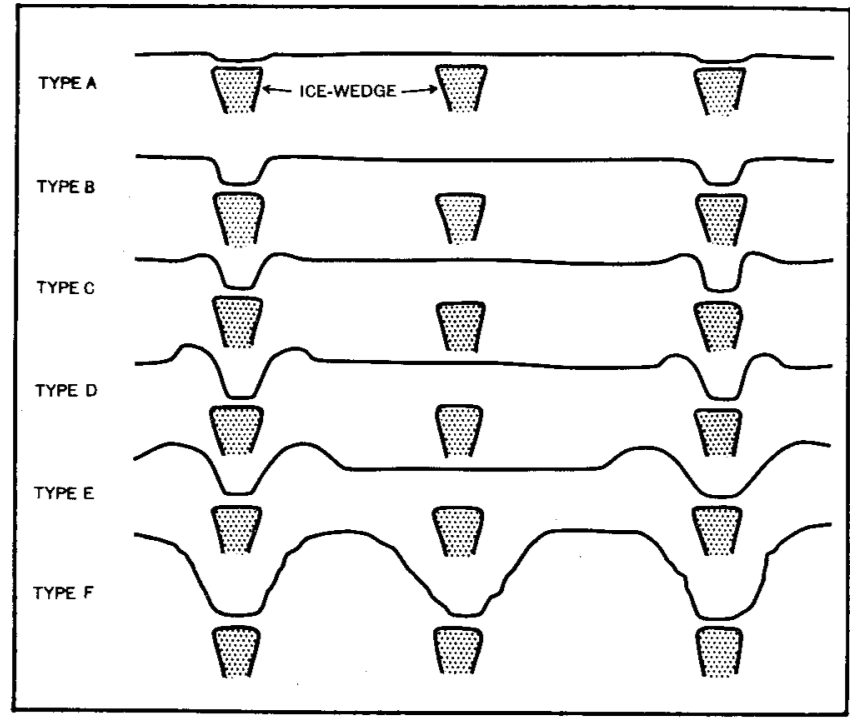

Fig. 5. Proposed classification of ice-wedge polygons associated with arctic soils.

\section{Summary}

Lithosols, Regosols, Arctic Brown, Upland Tundra, Meadow Tundra, and Bog soils have been recognized as the major genetic soils of northern Alaska. Highly variable soil conditions exist, however, when these soils are associated with patterned ground. Specific patterns of sorted and nonsorted circles, polygons, nets, steps, and stripes often occur with particular soils. Differences in soil conditions, vegetation, and microrelief exist across these forms of patterned ground in a closely associated complex governed by the kind of patterned ground. It is proposed that arctic soils be classified in terms of both the genetic soil profile and the kind of patterned ground.

\section{References}

Black, R. F. 1954. Permafrost-a review. Bull. Geol. Soc. Am. 65:839-56.

Douglas, L. A., and J. D. F. Tedrow. 1959. Organic matter decomposition rates in arctic soils. Soil. Sci. 88:305-12.

Drew, J. V. 1957. A pedologic study of arctic coastal plain soils near Point Barrow, Alaska. (Ph. D. thesis) Rutgers Univ. Library, New Brunswick, N.J. 117 pp. (unpublished).

Drew, J. V., J. C. F. Tedrow, R. E. Shanks, and J. J. Koranda. 1958. Rate and depth of thaw in arctic soils. Trans. Am. Geophys. Union 39:697-701.

Hopkins, D. M., and R. S. Sigafoos. 1950. Frost action and vegetation patterns on Seward Peninsula, Alaska. U. S. Geol. Surv. Bull. 974-C.

Tedrow, J. C. F. 1961. Morphological evidence of frost action in aretic soils. Biuletyn Perglacjalny (in press).

Tedrow, J. C. F., and J. E. Cantlon. 1959. Concepts of soil formation and classification in arctic regions. Arctic 11:166-79.

Tedrow, J. C. F., J. V. Drew, D. E. Hill, and L. A. Douglas. 1958. Major genetic soils of the arctic slope of Alaska. J. Soil Sci. 9:33-45.

Washburn, A. L. 1956. Classification of patterned ground and a review of suggested origins. Bull. Geol. Soc. Am. 67:823-66.

Wiggins, I. L. 1951. The distribution of vascular plants on polygonal ground near Point Barrow, Alaska. Contr. Dudley Herb., Nat. Hist. Mus., Stanford Univ. 4:41-56. 